\title{
15. The secret diary recording the depression of the imaginative woman narrator in Charlotte Perkins Gilman's “The Yellow Wall Paper”
}

Zennure KÖSEMAN ${ }^{1}$

APA: Köseman, Z. (2021). The Secret Diary Recording the Depression of the Imaginative Woman Narrator in Charlotte Perkins Gilman's “The Yellow Wall Paper”. RumeliDE Dil ve Edebiyat Araştırmaları Dergisi, (0̈9), 177-183. DOI: 10.29000/rumelide.981522.

\begin{abstract}
As reflected through the highly imaginative storyteller of Charlotte Perkins Gilman's "The Yellow Wall Paper" (1892), this article underlines how secret diaries kept in mind expose the inner worlds of individuals who expose what they have in their consciousness. As both a work of feminist literature and a work of psychological fiction, the target one indicates a fragmented female mind of the secretive narrator kept behind the wallpaper. Recording her thoughts about the wallpaper implies that the narrator, named as Jane or not Jane, is the stereotype representing such kind of women in society and keeps most of her thoughts behind the wallpaper. To illustrate, she has some conflicts existing between her and her husband so that she manifests them in her diary kept in mind through her writings. Although her husband seems to love his wife, yet, he does not understand the negative impact he has on her that indicates their alienation. Reflecting the existence of a strong inner/outer world distance in this short story, this article highlights that as the narrator alienates herself from the outer world, she comprehends her inner world realities better in her loneliness. In this case, the narrator has a great psychological suffering. She has great imagination and identifies herself as the trapped woman behind the wallpaper. In this case, she has an obssession of marginalizing herself with the wallpaper.
\end{abstract}

Keywords: Secret Diary, Depression, Great Imagination, Wallpaper, Inner/Outer World

\section{Charlotte Perkins Gilman'ın “The Yellow Wall Paper” adlı kısa hikâyesinde hayalperest kadın anlatıcı'nın depresyonunu kaydeden gizemli günlük}

\begin{abstract}
$\ddot{0} \mathrm{z}$
Charlotte Perkins Gilman'ın "The Yellow Wall Paper” (1892) adlı hikâyesinin oldukça hayalperest öykü anlatıcısı aracılığıyla yansıtıldığı üzere, bu makale, yazı yoluyla zihinde saklı tutulan gizli günlüklerin, bireylerin bilinçlerinde iç dünyalarında sahip olduklarını açığa çıkardığının altını çiziyor. Hem bir feminist kısa hikâyesi hem de bir psikolojik kurgu eseri olarak hedef, duvar kâğıdının arkasında anlatıcının gizemli parçalanmış kadın zihnini göstermektir. Duvar kâğıdıyla ilgili düşüncelerini kaydetmek, Jane olan ya da Jane olmayan, anlatıcının toplumdaki benzeri kadınları temsil eden stereotip olduğunu ve düşüncelerinin çoğunu duvar kâğıdının arkasında saklı tuttuğunu ima eder. Örneğin, günlüğünde kocasıyla arasında bazı çatışmaların olduğunu belirtir. Kocası karısını seviyor gibi görünse de, O'na yabancılaştığını gösteren olumsuz etkisini anlamıyor. Güçlü bir iç / dış dünya mesafesine sahip olan bu kısa hikâye, anlatıcının kendisini dış dünyaya yabancılaştıırken, içsel gerçeklerini yalnızlığında daha iyi anladığını vurgulamaktadır. Bu durumda anlatıcının büyük bir psikolojik ıstırabı vardır. Harika
\end{abstract}

Doç. Dr., İnönü Üniversitesi, Fen-Edebiyat Fakültesi, Batı Dilleri ve Edebiyatları Bölümü, (Malatya,Türkiye). zennure.koseman@inonu.edu.tr. ORCID ID: 000000023420 9801. [Araştırma makalesi, Makale kayıt tarihi: 07.07.2021-kabul tarihi: 20.06.2021; DOI: 10.29000/rumelide.981522]

Adres

RumeliDE Dil ve Edebiyat Araştırmaları Dergisi Osmanağa Mahallesi, Mürver Çiçeği Sokak, No:14/8 Kadıköy - ISTANBUL / TÜRKIYE 34714 e-posta: editor@rumelide.com tel: +90 $5057958124,+902167730616$
Address

RumeliDE Journal of Language and Literature Studies

Osmanağa Mahallesi, Mürver Çiçeği Sokak, No:14/8

Kadıköy - ISTANBUL / TURKEY 34714

e-mail: editor@rumelide.com,

phone: +90 505 7958124, +90 2167730616 
The Secret Diary Recording the Depression of the Imaginative Woman Narrator in Charlotte Perkins Gilman's "The Yellow Wall Paper" / Z. Köseman (pp. 177-183)

bir hayal gücü olan kadın, kendini duvar kâğıdının arkasındaki hapsolmuş kadın olarak tanımlıyor. Bu durumda, duvar kâğıdıyla kendini ötekileştirme takıntısı vardır.

Anahtar kelimeler: Gizli günlük, depresyon, büyük hayal gücü, duvar kâğıdı, iç / dıș dünya

\section{The Secret Diary Recording the Depression of the Imaginative Woman Narrator in Charlotte Perkins Gilman's "The Yellow Wall Paper"}

Charlotte Perkins Gilman's highly imaginative woman narrator in "The Yellow Wall Paper" (1892) explores the secret narrative formation that embodies significant meaning as described with the yellow wallpaper. Those imageries emphasize the existence of a mysterious world produced by the yellow wallpaper in the room of the haunted house. Having a psychoanalytic perspective, reseachers and readers concern the definition of a new way of living that depicts how the storyteller recounts her mental confusion and her depressive psyche. Through comprehending the meaningfulness of the yellow wallpaper, the narrator, accordingly, expresses the social as well as the psychic problematic cases of her own life (Hochman 132). In this case, she substantially reads the yellow wallpaper distintively and defines the strangeness in it. Gilman is the new woman who explains women protagonists with their new mind and body concept. Although, the narrator as the main character is explained as a psychologically problematic person and referred as sick, she is the one who has a new awakening to be aware of herself. So, Gilman concerns "the new woman" who regards female health and mind-body relationship (Vertinsky 1989: 6). This emphasizes that Gilman is focusing on the female worlds, therefore, she has a feminist outlook. As she concerns female living, Gilman focuses

primarily on the nineteenth century, literature of the period often characterized women as victims oppressed by society, culture, as well as by the male influences in their lives. Many of the female characters suffered the effects of isolation brought on by constant oppression and subservience driving them insane and mad. The views of women in early literature were often silenced and their opinion's disregarded by a dominant patriarchal society. (Muhi 2010: 3)

As this short story belongs to the late nineteenth century literary period, then, it is signifcant to express how women are suffering from isolation and approaximately becoimg mad deriving from the authority of the patriarchal society. Although Charlotte Perkins Gilman's "The Yellow Wall-Paper" was read as a Gothic horror tale most of the time, after "Elaine Hedges rediscovered the story and republished it in the Feminist Press in 1973," it has been evaluated in feminist perspectives. In this case, it is possible to consider the target short story predominantly as a feminist text. It is significant that this short story can be considered in many perspecives such as feminine as well as biograpical, deconstructive, psychoanalytical, and medical (Wolter 2009: 195). Thus, several approaches to this short story hint that it is accomplishable to evaluate from different world views. It is an affluent story that affects researchers from several perspectives.

When the narrator, the main character, in the target short story, reflects her inner world on papers, she, accordingly, intends to emphasize the secret existence of her own secret diary kept in her mind. It is secret, because it is directly forbidden for women to experience writing about their own thoughts and feelings at that period. Therefore, the narrator in this short story as a secret mission performs writing psychologically. As she writes herself every day, then, it is proper to define it as a secret diary that defines her depressive situation through viewing the yellow wallpaper. In this case, Gilman has a psychoanalytic outlook and depicts her secret narrative formation having valuable imageries within the yellow wallpaper. As Elaine Showalter explains, Gilman reflects a hysterical narrative and states a "fragmented, evasive, and ambiguous" way of narration (Showalter 24). She entirely depicts a fragmented character who is away from other individuals.

$$
\begin{aligned}
& \text { Adres } \mid \begin{array}{ll}
\text { Address } \\
\text { Adres }
\end{array} \\
& \text { RumeliDE Dil ve Edebiyat Araştırmaları Dergisi } \quad \text { RumeliDE Journal of Language and Literature Studies } \\
& \text { Osmanağa Mahallesi, Mürver Çiçeği Sokak, No:14/8 } \quad \text { Osmanağa Mahallesi, Mürver Çiçeği Sokak, No:14/8 } \\
& \text { Kadıköy - İSTANBUL / TÜRKIYE } 34714 \text { Kadıköy - ISTANBUL / TURKEY } 34714 \\
& \text { e-posta: editor@rumelide.com e-mail: editor@rumelide.com }
\end{aligned}
$$

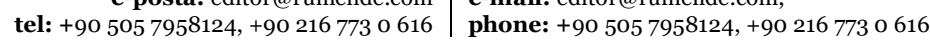


Gilman wrote this semi-autobioraphical short story to be critical about her doctor, Silas Weir Mitchell, who diagnosed her with hysteria and had a treatment of having a rest cure for her. However, this treatment restricts bodily and mental freedoms as depicted with restricting the life of the narrator with the haunted house covered by a yellow wallpaper. After having this medical treatment, Gilman wrote the "The Yellow Wallpaper" with a narrator who had the same rest cure. Being considered as ill, the narrator had a diagnosis of "slight hysterical tendency" (Gilman 2; Delchamps 105). In this case, having a semi-autobiographical mental illness, she represents a psychologically problematic case and becomes a subject for study as indicated through the psychoanaltical outlook of this article. The narrator as a hysterical person locks herself in the room of the haunted house and feels safe there. Virgina Woolf can be referred to emphasize how she stays in the the yellow wallpaper and regards it possessing as her own room. The narrator is entirely alone in her life and creates her new imaginary world there. She has a new understanding in the room that the yellow wallpaper exists in. She has a rebirth, a reawakening with herself and, as a whole, a change with her living. She has the existence of epiphany to consider everything clearly (Özer 78).

Similar to Virginia Woolf's writing A Room of One's Own in later years, Gilman exemplifies the narrator being in a haunted house where they pass their summer holiday. Gilman depicts depressive female genders by creating a narrator protagionist in "The Yellow Wallpaper." She intends to have a room of her own and be alone. However, what is interesting is that the narrator in Gilman's short story previously defines her "room of her own" in the 1890s and experiences her secret psychological formation via her writings kept in her mind. Therefore, Gilman becomes a representative writer that sets forth female isolated alternative worlds kept behind the yellow wallpaper in the haunted house (Horowitz 3). The female narrator as a lonely individual, even in her marriage life, creates an imaginary living behind the wallpaper and voices her own depressive cases through expressing herself in her own writings. She has imageries for herself in the room and defines all of them in different explanations. The yellow wallpaper symbolizes her anger, depression and secret living whereas the house represents her alienation from her environment. Yet, she feels selfconfident by writing her psychological state signifying that she is content with her finding a room of her own in that house.

The narrator explains the room in her writings as "A colonial mansion, a hereditary estate, I would say a haunted house, and reach the height of romantic felicity--but that would be asking too much of fate! Still I will proudly declare that there is something queer about it" (Gilman 1). As this quotation implies, she considers the room as a "haunted" one having romantic living in it. It is significant to express that this short story concurrently has the elements of the gothic horror story. As the setting is a "colonial mansion" that has "hereditary estate," it also states being a "haunted house." Similarly, the narrator's mind is full of "fervid imagination" as a haunted house (Notaro 2). In her mind having a "haunted house" representation, she feels herself free by writing her psychological diary that exists in her own mind.

The narrator accepts herself to be psychologically sick enough when her "physician of high standing, and one's own husband, assures friends and relatives that there is really nothing the matter with one but temporary nervous depression--a slight hysterical tendency" (Gilman 2). As this quotation specifies, the physician husband has the authority at home and has supremacy in marriage. The male voice speaks in the haunted house, however, the narrator wife has mental distress. She should control herself ironically better in that silence of the room as the physcian husband suggests (Horowitz 177) she should achieve overcoming her nervous illness. She is advised by her physician husband to have "rest, air, absence of stimulation and a ban on writing" (Horowitz 178). However, having a ban of writing is entirely to punish her and to let her be away from having a released mind. This emphasizes that her "nervous depression" seems not to end by being locked in the room having yellow wallpaper in it. life Her mental distress is

Adres

RumeliDE Dil ve Edebiyat Araştırmaları Dergisi Osmanağa Mahallesi, Mürver Çiçeği Sokak, No:14/8 Kadıköy - ISTANBUL / TÜRKIYE 34714 e-posta: editor@rumelide.com tel: +90 $5057958124,+902167730616$
Address

RumeliDE Journal of Language and Literature Studies

Osmanağa Mahallesi, Mürver Çiçeği Sokak, No:14/8

Kadıköy - ISTANBUL / TURKEY 34714

e-mail: editor@rumelide.com,

phone: +90 5057958124, +90 2167730616 
multiplied when she is forced to ban writing for herself. She no longer sleeps much at nights, because she regards it to be a very different place to reside. She watches all the developments in it carefully (Hochman 130). Therefore, there is the augmentation of an alternative world existing behind the yellow wallpaper for the narrator. She thinks that the house has a very different outlook and, yet, she is happy with it because of its implying her alienation both in her inner and outer worlds:

The most beautiful place! It is quite alone, standing well back from the road, quite three miles from the village. It makes me think of English places that you read about, for there are hedges and walls and gates that lock, and lots of separate little houses for the gardeners and people. There is a DELICIOUS garden! I never saw such a garden--large and shady, full of box-bordered paths, and lined with long grape-covered arbors with seats under them. (Gilman 2)

As expressed in the quotation, the beautiful setting is quite away from all the mentioned places for the woman narrator: far away from the bridge, gardens, and the inhabitants living there. For the narrator, it has a brilliant outlook. Moreover, the room that is locked with the gates having hedges and walls is a wellcovered place to live in. However, she is not entirely content with it "I wanted one downstairs that opened on the piazza and had roses all over the window, and such pretty old-fashioned chintz hangings! but John would not hear of it." (Gilman 3). Yet, her physician husband is not aware of all these. Because, he said they came to let the narrator have "perfect rest" and have all the fresh air there. "Your exercise depends on your strength, my dear,' said he, 'and your food somewhat on your appetite; but air you can absorb all the time.' So we took the nursery at the top of the house." (Gilman 3). Accordingly, the husband concerns the wife as a hysterical person and follows her to have strength. She creates new imageries existing behind the yellow wallpaper:

\begin{abstract}
The paint and paper look as if a boys' school had used it. It is stripped off--the paper--in great patches all around the head of my bed, about as far as I can reach, and in a great place on the other side of the room low down. I never saw a worse paper in my life. One of those sprawling flamboyant patterns committing every artistic sin. It is dull enough to confuse the eye in following, pronounced enough to constantly irritate and provoke study, and when you follow the lame uncertain curves for a little distance, they suddenly commit suicide--plunge off at outrageous angles destroy themselves in unheard of contradictions. The color is repellent, almost revolting; a smouldering unclean yellow, strangely faded by the slow-turning sunlight. It is a dull yet lurid orange in some places, a sickly sulphur tint in others. (Gilman 2)
\end{abstract}

This quotation entirely depicts the existence of an alternative world for the narrator. However, although she describes a distinct setting in that room, she does not express her being destroyed by it. The changes in the sunlight represents her creation of new imageries in the room. Its being "dull enough" due to confusing the eyesight is the reason for uncertainity. As it is clear, the yellow wallpaper has a revolt in it: "it is a dull yet lurid orange" so everything fades by the changing sunlight. She reflects all this changing format in her secret diary by hiding it from her husband and her sorrounding. The narrator in the target short story explains how she is disgusted by the others, because, when they see her writing, they just express how they dislike seeing her experiencing it:

There comes John, and I must put this away,-- he hates to have me write a word. We have been here two weeks, and I haven't felt like writing before, since that first day. I am sitting by the window now, up in this atrocious nursery, and there is nothing to hinder my writing as much as I please, save lack of strength. (Gilman 3-4)

This quotation is signicant to specify how she feels herself powerful when she defines her inner world through writing. She acquires her strength and becomes self-confident of herself. Although she sometimes states the strangeness of the yellow wallpapered room, she confesses its inspirational strength to have individuals obtain an initiation process to comprehend the significance of values for themselves. The

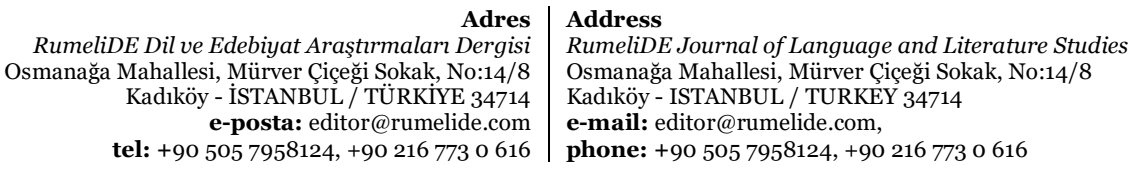


narrator becomes aware of her own being in living. To illustrate, the narrator professes that she hasn't felt herself ready for writing before, yet, this room awakens herself to have a new identity away from all her problematic matters in her life both psychologically and socially. Her new identification, accordingly, is a hint to guess that the "nervous troubles are dreadfully depressing" her (Gilman 4). This reflects that her husband John is not aware of the fact how much she suffers. He solely regards that there is no cause to suffer, and that he becomes content with disregarding her suffrage (Gilman 4). Therefore, there is a strong lack of communication between the wife and the husband. He has indifference towards the realities of her psychological illness. When the narrator feels herself happy in this yellow wallpapared room, she begins to be fond of it, yet, she is aware of the fact that it is "all but that horrid paper" (Gilman 4). She starts to write energetically because of defining herself better since the first day of coming to the haunted house (Gilman 4). She professes directly about her "habit of story-making." She indicates her writing is a means to relieve her inner world and she expresses, "I think sometimes that if I were only well enough to write a little it would relieve the press of ideas and rest me. But I find I get pretty tired when I try" (Gilman 4-5). In addition to her resting when she writes, she feels concurrently tired when she strives hard to write. Her tiredness is multiplied when she entirely has the sense of being disturbed of her husband and the other individuals sorrounding her as they hate her writing there:

There comes John's sister. Such a dear girl as she is, and so careful of me! I must not let her find me writing. She is a perfect and enthusiastic housekeeper, and hopes for no better profession. I verily believe she thinks it is the writing which made me sick! (Gilman 5)

This quotation depicts others' following her in her living environment. Although she is content with her diary kept in her mind, the others concern her as a psychologically sick person. They are not aware of the fact that she is overcoming her alienation from the whole world through her writing. She and her diary in which she notes her daily memoirs signifies her inner world. She is happy for dwelling in the room having the yellow wallpaper with special signs. She remarks, "I am too wise, - but I keep watch of it all the same. There are things in that paper that nobody knows but me, or ever will. Behind that outside pattern the dim shapes get clearer every day. It is always the same shape, only very numerous" (Gilman 6).

As the quotation from this short story signify, there are specific signs on the wallpaper so that they have special meanings for the narrator: nobody but only the narrator can define them. It is an important room that dwells in the narrator's mind (Gilman 6). However, she becomes sad by the time when her husband reminds her about the approaching time of departure from the haunted hause:

I quite enjoy the room, now it is bare again. How those children did tear about here! This bedstead is fairly gnawed! But I must get to work. I have locked the door and thrown the key down into the front path. I don't want to go out, and I don't want to have anybody come in, till John comes. I want to astonish him. I've got a rope up here that even Jennie did not find. If that woman does get out, and tries to get away, I can tie her! But I forgot I could not reach far without anything to stand on! This bed will NOT move! .I am getting angry enough to do something desperate. To jump out of the window would be admirable exercise, but the bars are too strong even to try. (Gilman 13)

As the stated quotation reflects, the narrator is unfortunately thinking about committing suicide through jumping. Thus, she thinks of suicide attempt and she rejects leaving the room. The room in the haunted house has entirely captured her and, therefore, her alienation ends as she regards not to be an alone person in that room. This emphasizes that she overcomes her alienation and feels safe and self-confident in that haunted house. In this case, she concerns the room as meaningful so that it entirely nanifests her mental confusion. Behind the wall, she views her depressed situation:

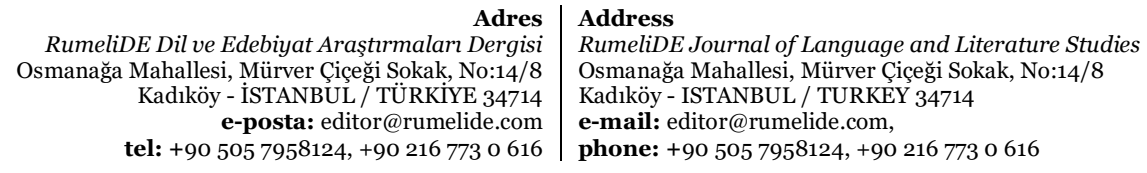

RumeliDE Dil ve Edebiyat Araştırmaları Dergisi tel: +90 $5057958124,+902167730616$ 
There are things in that paper that nobody knows but me, or ever will. Behind that outside pattern the dim shapes get clearer every day. It is always the same shape, only very numerous. And it is like a woman stooping down and creeping about behind that pattern. I don't like it a bit. I wonder--I begin to think--I wish John would take me away from here! (Gilman 8)

Moreover, there are many things that nobody knows behind that wallpaper. She and the wall are carrying mysterious meanings with them, therefore, she finds an other way to release herself in that quiet and safe room. Although it seems to have silence in it, accordingly, it has fear and mysterious living in it. Thus, it is horrible enough psycholgically so that she is there to be locked in the room. In her "Introduction," Helen Lefkowitz Horowitz becomes critical of the meaningfulness behind the Yellow Wallpaper:

\begin{abstract}
Much of the power behind "The Yellow Wall-Paper" derives from its author's intimate knowledge of mental affliction. In this chronicle, a troubled woman-kept isolated by her physician-husband in an upstairs room in a country house, prevented from writing, and deprived of the stimulation of companydescends from nervous illness into madness. The story's central character and narrator takes the reader on every step of her downward course. (Horowitz 3)
\end{abstract}

As a conclusion, the narrator expresses herself better with confusion in the yellow wallpaper as it expresses her own mental confusion. She unites herself with the wallpaper and feels to be safe by living there. The reason why she does not want to leave the house is that she shares her own loneliness with it. Nobody can understand her in her own life, but, she has "a room of her own" and becomes safe and self-confident in it. Such a change with her emphasizes that she had a rebirth with herself to consider most of the things from a new perspective. She becomes a new woman with the new room existing in the haunted house having the yellow wallpaper in it. Accordingly, the narrator has an initiation process to comprehend her essence better. Therefore, she attains a reawakening in her new environment.

\title{
Bibliography
}

Delchamps, Vivian. (2020). "A Slight Hysterical Tendency" Performing Diagnosis in Charlotte Perkins Gilman's "The Yellow Wallpaper." Performing Hysteria: Images and Imaginations of Hysteria. Leuven University Press, 105-124. Retrieved June 20, 2021, from https://www.jstor.org/stable/j.ctv18dvt2d.9.

Gilman, Charlotte Perkins (Stetson). (2008). The Yellow Wallpaper. (1952). Gutenberg EBook The Yellow Wallpaper. Pp. 647-656. Retrieved 10 June, 2021, from https://libgen.is/book/index.php?md5=E0F60AD27DC9875AE332EE3D24AF9E74.

Horowitz, Helen Lefkowitz. (2010). Wild Unrest: Charlotte Perkins Gilman and the Making of the "Yellow Wallpaper." Oxford: Oxford University Press. Retrieved from Library of Congress Cataloging on June 10, 2021.

Hochman, Barbara. (2005). The Reading Habit and 'The Yellow Wallpaper'. In Badia J. \& Phegley J. (Eds.), Reading Women: Literary Figures and Cultural Icons from the Victorian Age to the Present (pp. 129-148). University of Toronto Press. Retrieved June 18, 2021, from http://www.jstor.org/stable/10.3138/j.ctt2tv2v1.10

Muhi, Maysoon Taher (2010). Madness is the Divinest Sense: Madness in Charlotte Perkins Gilman's 'The Yellow Wallpaper'." University of Baghdad. Retrieved June 19, 2021, from https://www.researchgate.net/publication/321275967_Madness_is_the_Divinest_Sense_Madness_i n_Charlotte_Perkins_Gilman's_The_Yellow_Wallpaper

Özer, Sevinç Sayan. (2018). “Amerikan ve Türk Kısa Öyküsünde 'Initiation:' Hayata Başlangıç Öyküsü.” Çağdaş Kısa Öykü Sanatı ve Politikaları. Ankara: İmge Kitapevi, 75-97.

Showalter, Elaine. (1993). "On Hysterical Narrative." Narrative. Vol. 1, No. 1. Ohio State University Press. Pp.: 24-35. Retrieved June 16, 2021, from https://www.jstor.org/stable/20106990

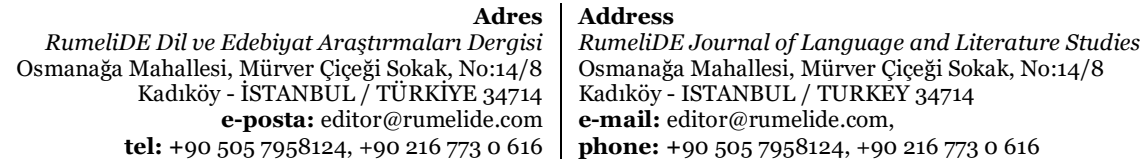

RumeliDE Dil ve Edebiyat Araştırmaları Dergis tel: +90 $5057958124,+902167730616$ 
Vertinsky, Patricia. (1989). “Feminist Charlotte Perkins Gilman's Pursuit of Health and Physical Fitness as a Strategy for Emancipation." Journal of Sport History. Vol. 16, No. 1 (Spring, 1989), pp. 5-26. Retrieved June 18, 2021, from https://www.jstor.org/stable/43609379

Wolter, Jürgen. (2009). "The Yellow Wall-Paper": The Ambivalence of Changing Discourses. Amerikastudien / American Studies. Vol. 54, No. 2. pp. 195-210. Universitatverlag winter Gmbh. Retrieved June 19, 2021, from https://www.jstor.org/stable/41158426.

Adres
RumeliDE Dil ve Edebiyat Araştırmaları Dergisi Osmanağa Mahallesi, Mürver Çiçeği Sokak, No:14/8 Kadıköy - İSTANBUL / TÜRKIYE 34714 e-posta: editor@rumelide.com tel: +90 $5057958124,+902167730616$
Address

RumeliDE Journal of Language and Literature Studies Osmanağa Mahallesi, Mürver Çiçeği Sokak, No:14/8

Kadıköy - ISTANBUL / TURKEY 34714

e-mail: editor@rumelide.com

phone: +90 505 7958124, +90 2167730616 